\title{
Sexual dimorphism in Ozopherus muricatus Pascoe, 1872 (Coleoptera: Curculionidae)
}

\author{
Dimorfismo sexual em Ozopherus muricatus Pascoe, 1872 \\ (Coleoptera: Curculionidae)
}

\author{
Núbia Lima dos Santos', Kelly Barbosa da Silva ${ }^{2,3}$, Ellen Rebecca Lopes de Oliveira', \\ Henrique Fonseca Goulart ${ }^{4}$, Antonio Euzébio Goulart Santana ${ }^{1,2,3}$, Elio Cesar Guzzo ${ }^{1,5 *}$ (DD
}

\begin{abstract}
The weevil Ozopherus muricatus Pascoe, 1872 (Coleoptera: Curculionidae) is already considered a pest in Brazil for açaí palm (Euterpe oleracea Mart.) plantations. Its presence has become more frequent and caused significant reduction in the production of açaí fruit. Studies on the biology of this insect pest are still scarce, hindering its management. For studies on pheromones, for instance, it is essential to correctly identify the sex of the insect. The objective of this study was to evaluate the existence of sexual dimorphism in pupae and adults of $O$. muricatus in order to allow the identification of males and females. Larvae, pupae and adults were collected from açaí plantations and kept in biochemical oxygen demand (BOD) type incubation chambers. Adults and pupae were examined under a stereomicroscope, and dimorphism was determined through observation of external morphological characteristics. In addition, adults were dissected in order to observe genitalia and confirm the sex of specimens. In the pupae, sexual dimorphism was characterized by the presence of two protuberances in the terminal ventral region of the abdomen of females, which were absent in males. In adults, sexual dimorphism was also observed, based on the final abdominal segments. In males, it was possible to see all eight abdominal tergites, while in females tergite VIII is covered by tergite VII. Thus, the sexual dimorphism present in the morphological characteristics of $O$. muricatus allows the distinction between males and females of this species.
\end{abstract}

KEYWORDS: morphology; sex differentiation; sex determination; açaí palm; Arecaceae.
RESUMO: O gorgulho Ozopherus muricatus Pascoe, 1872 (Coleoptera: Curculionidae) já é considerado uma praga em plantações de açaí (Euterpe oleracea Mart.) no Brasil. Sua presença tem se tornado mais frequente e causado redução significativa na produção de frutos. Estudos sobre a biologia dessa praga ainda são escassos, dificultando o seu manejo. Para estudos com feromônios, por exemplo, é essencial a correta identificação do sexo do inseto. O objetivo deste estudo foi avaliar a existência de dimorfismo sexual em pupas e em adultos de $O$. muricatus, a fim de permitir a identificação de machos e fêmeas. Larvas, pupas e adultos foram coletados de plantaçóes de açaí e mantidos em câmaras incubadoras para demanda bioquímica de oxigênio (DBO). Adultos e pupas foram examinados sob microscópio estereoscópico, e o dimorfismo foi determinado por meio da observação de características morfológicas externas. Adicionalmente, adultos foram dissecados para a observação da genitália e confirmação do sexo dos espécimes. Nas pupas, o dimorfismo sexual foi caracterizado pela presença de duas protuberâncias na região terminal ventral do abdome das fêmeas, as quais foram ausentes nos machos. Nos adultos, também se observou dimorfismo sexual, com base nos segmentos finais do abdome. Nos machos, é possível visualizar todos os oito tergitos abdominais, enquanto nas fêmeas o tergito VIII é encoberto pelo tergito VII. Assim, o dimorfismo sexual presente nas características morfológicas de $O$. muricatus permite distinção entre machos e fêmeas dessa espécie.

PALAVRAS-CHAVE: morfologia; diferenciação sexual; determinação sexual; açaizeiro; Arecaceae.

'Programa de Pós-Graduação em Proteção de Plantas, Universidade Federal de Alagoas (UFAL) - Rio Largo (AL), Brazil ${ }^{2}$ Programa de Pós-Graduação em Biotecnologia, UFAL - Maceió (AL), Brazil

${ }^{3}$ Laboratório de Pesquisa em Recursos Naturais, Departamento de Química e Biotecnologia, UFAL - Maceió (AL), Brazil

${ }^{4}$ Centro de Ciências Agrárias, UFAL - Rio Largo (AL), Brazil

${ }^{5}$ Embrapa Tabuleiros Costeiros - Aracaju (SE), Brazil

*Corresponding author: elio.guzzo@embrapa.br

Received on: 03/05/2017. Accepted on: 05/10/2018

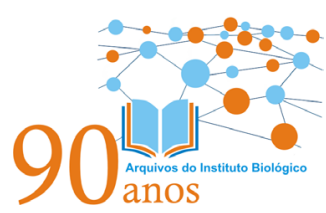


The açaí palm (Euterpe oleracea Mart.) is a species of palm tree belonging to the family Arecaceae. Its cultivation is widely distributed in Brazil, mainly in the North, but also found in other Brazilian regions and in some countries of South and Central America (OLIVEIRA, 2002; NOGUEIRA et al., 2005). In Brazil, extractive production of açaí reached 215,609 tons of fruit in 2016, and Pará and Amazonas were the top producing states, contributing with 61.2 and $26.7 \%$ of the total production, respectively (IBGE, 2017).

Açaí has gained significant economic visibility within Brazil and also in the United States, Japan and Europe, for its fresh consumption, as well as several other derivative products, such as drinks and cosmetics. The importance of this species to the nutritional, cosmetic and pharmaceutical industry is due to the presence of flavonoids, phenolics and anthocyanins, which have antioxidant, anti-inflammatory, and anti-malaria activities (YAMAGUCHI et al., 2015; BARBOSA et al., 2016).

The large commercial growth of açaí has generated an expansion of cultivated areas, with a consequent increase in the incidence of pests in these plantations, causing significant economic harm to its development and production (SOUZA, 2002). The weevil Ozopherus muricatus Pascoe, 1872 (Coleoptera: Curculionidae) (Fig. 1) is an endemic species in the Amazon region, and has gained great visibility due to its deleterious effects on açaí palm cultivation, causing up to $42 \%$ of loss of fruit bunches and becoming a pest with the potential to cause major damage (TREVISAN; OLIVEIRA, 2012).

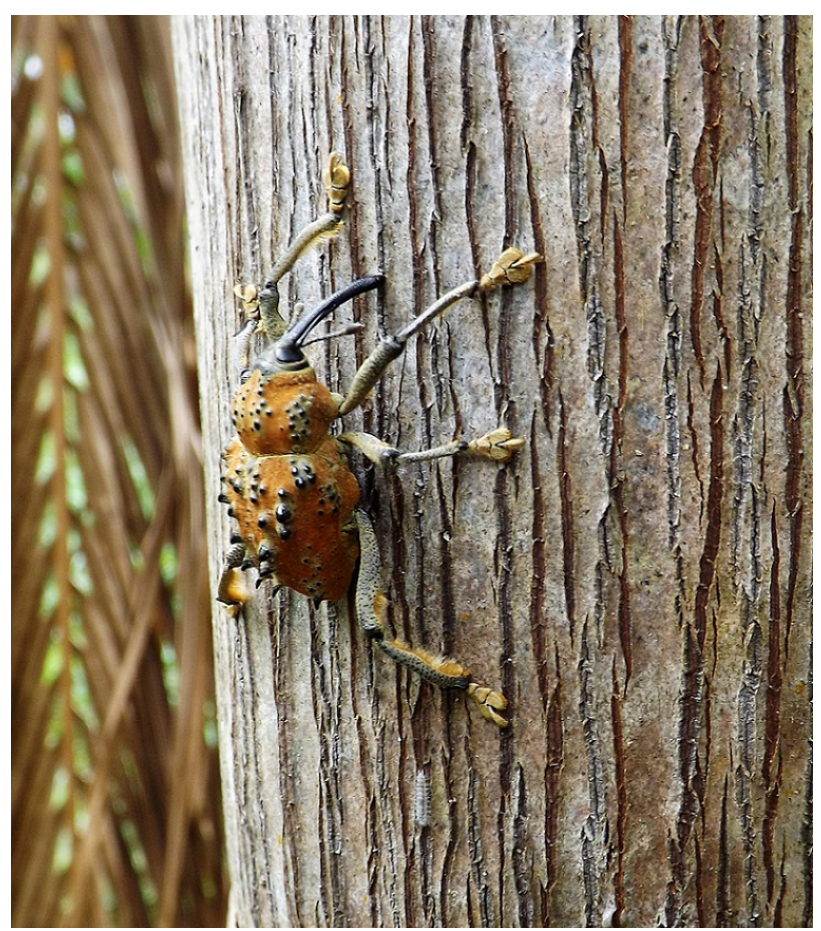

Figure 1. Adult of Ozopherus muricatus Pascoe, 1872 (Coleoptera: Curculionidae) on açaí palm, in the municipality of Buritis, Rondônia, Brazil.
There are few studies on the biology and control methods for O. muricatus. The generation of information directed at differentiating males and females of this species is an important factor to support studies related to reproductive behavior and sex ratio, among others, as well as contribute significantly to the development of control methods for this pest (FERNANDES et al., 2005; CORDEIRO et al., 2011; FONSECA et al., 2014).

VAURIE (1973), when describing the species O. muricatus, tried to correlate the size and shape of the spines of elytra with the sex of individuals, but dissection of the specimens revealed no such correlation, due to wear and tear of the spines during the life of the insect. In addition, other characteristics normally associated with one of the sexes in Curculionidae, such as rostrum size, pilosity and point of insertion of the antennae, or pilosity of the legs or venter, are also absent in $O$. muricatus.

Thus, the objective of this study was to identify sexual dimorphism in $O$. muricatus, recording characteristics that allow the recognition of males and females and support new research on the biology and control of this insect pest.

Larvae, pupae and adults of $O$. muricatus were collected in açaí palm plantations located in the municipality of Buritis, Rondônia, Brazil, and sent to the laboratory. Larvae and pupae were kept individually in plastic containers $(5 \mathrm{~cm}$ in height $\times$ $5.5 \mathrm{~cm}$ in diameter) in a biochemical oxygen demand (BOD) type incubator chamber, at temperature of $25 \pm 1^{\circ} \mathrm{C}$, relative humidity (RU) of $80 \pm 5 \%$ and photoperiod of 0L:24D. The larvae were fed with pieces of sugarcane (Saccharum officinarum) (Poaceae) stalk, replaced twice a week, and the pupae containers were lined with moistened filter paper until the adults emerged. Adults were kept in larger plastic containers $(30 \times 10 \times 35 \mathrm{~cm})$, with 30 insects/container, at $26 \pm 1^{\circ} \mathrm{C}$, $80 \pm 5 \% \mathrm{RU}$ and photoperiod of 12L:12D) and fed with pieces of sugarcane stalks replaced three times a week. The age and reproductive status of adults, considering that they were from field collections, were unknown.

For the determination of sexual dimorphism, 193 adults and 20 pupae of $O$. muricatus from the field were examined under a stereoscope at magnification of $40 x$, to observe characteristics that would provide information for differentiation of their sex. The 20 adults that emerged from pupae were also examined, and characteristics of both phases were compared with those of adult insects collected in the field, whose sex we have presumably identified by copulation observation. To confirm the sex of the insects, the specimens were dissected under a stereoscope (magnification of 40x), using microforceps and scissors.

We have identified morphological characteristics associated with $O$. muricatus males and females in both pupae and adults. In the pupal stage, we observed that females have two round protuberances close to the terminal ventral region of the abdomen (Fig. 2A), which were absent in male pupae (Fig. 2B). In the adults, morphological characteristics that indicate sexual 
dimorphism were observed in the dorsal region of the final abdominal segments of the insect, under the wings. In males, eight abdominal tergites could be observed (Fig. 2C), while in females, only seven abdominal tergites were visible, such that tergite VIII was completely covered by tergite VII (Fig. 2D), which contributes to the distinction of sex in this species.

The sexual dimorphism observed in $O$. muricatus perfectly matches with that described by SARRO et al. (2004) for Homalinotus coriaceus (Gyllenhal, 1836). It may be related to the fact that the genus $O z o p h e r u s$ is phylogenetically closer to the genus Homalinotus, with which it shares a number of other features in common (VAURIE, 1973).

In the pupae, round protuberances present in females and absent in males have also been described in other species of the Curculionidae family (BARRETO et al., 1999; SARRO et al., 2004; SOUSA et al., 2004; GOSIK et al., 2010).

The difference found in the tergites of adult males and females is a characteristic that has also been observed in other species of weevils (SARRO et al., 2004; SILVAFILHO et al., 2007; BARRETO; ROSADO-NETO, 2012). Such morphological characteristics can be easily observed with the naked eye and allow the identification of sex. The final abdominal segments can be moved down from the elytra with tweezers, for viewing without damaging them. Better visualization is obtained when beetle elytra are open, but, in the case of $O$. muricatus, opening the elytra is hampered, because they couple to each other and by the presence of spines. Thus, anesthetizing the insects in a freezer is an alternative that helps to keep them static, permitting to move the final abdominal segments down from the elytra and to view them.

The dissection process is used for sexual confirmation of many insects, corroborating sexual identity based on morphological characteristics (NUNES et al., 2009; GEORGE et al., 2015). In this study, the dissection of adult insects also confirmed the sexual identification of $O$. muricatus obtained
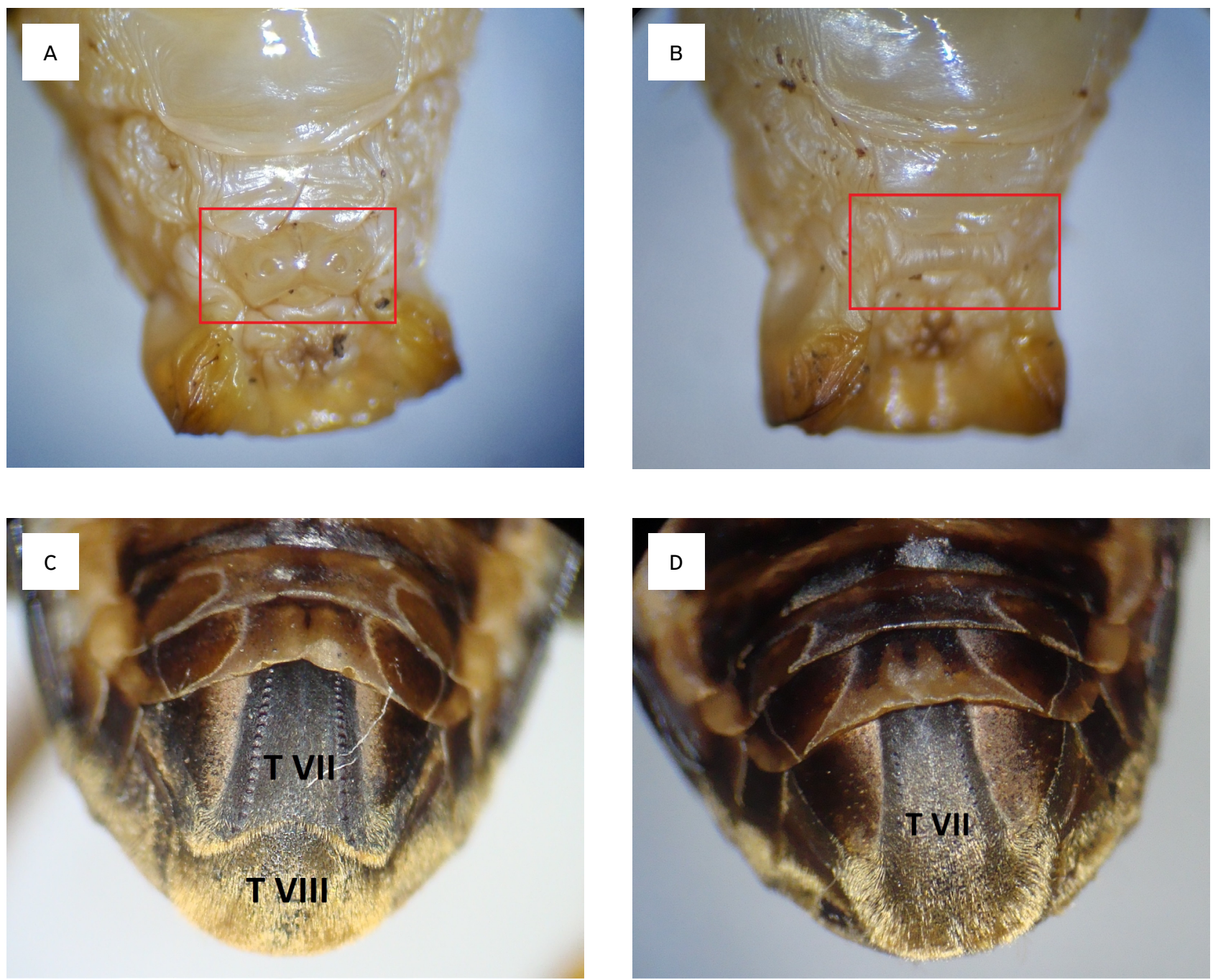

T VII: tergite VII; T VIII: tergite VIII.

Figure 2. Sexual dimorphism in Ozopherus muricatus Pascoe, 1872 (Coleoptera: Curculionidae). (A) Protuberances in the terminal ventral region of female pupa; (B) absence of protuberances in the terminal ventral region of male pupa; (C) tergites VII and VIII visible on the abdominal dorsal region of adult male; (D) tergite VII covering tergite VIII in the abdominal dorsal region of adult female. 
by observing the terminal tergites in adults and protuberances on the ventral surface of the abdomen of pupae.

External features observed in adults of other species of the Curculionidae family that could constitute sexual dimorphism, such as length, width and pilosity of the rostrum; point of insertion of the antennae in the rostrum; and pilosity of legs or venter (VAURIE, 1973; BARRETO et al., 1999; AMBROGI et al., 2009; WILHELM et al., 2011; BARRETO; ROSADO-NETO, 2012; CAZADO et al., 2014; GEORGE et al., 2015), were not found in O. muricatus, coinciding with observations pointed out by VAURIE (1973).

The population of $O$. muricatus we obtained from the field was composed by 124 males and 69 females, resulting in the sex ratio (number of females/number of males + females) of 0.36 . However, our study was not extensive enough to allow us to infer that this is the natural sex ratio for the species.
The results presented in this study provide important information about sex differentiation in O. muricatus, which may be useful for future works with this species, such as biology and chemical ecology, and for developing pest management tools.

\section{ACKNOWLEDGEMENTS}

To Coordenação de Aperfeiçoamento de Pessoal de Nível Superior (CAPES), for financial support throughout the development of this project; and to the Semiochemicals in Agriculture (Semioquímicos na Agricultura) of Instituto Nacional de Ciência e Tecnologia (INCT). To Mr. Peter Ozeis Maifrede, for his availability in the collection of insects.

| | | | | | | | | | | | | | | | | | | | | | | | | | | | | | | | | | | | | | | | | | | | | | | | | | | | | | | | | | | | | | | | | | | | | | | | | | | | | | | | | | | | | | | | | | | | | | | | | | | | | | | | | | | | | | | | | | | | | | | | | | | | | | | | | | | | | | | | | | | | | | | | | | | | | | | | | | | | | | | | | | | | | | | | | | | | | | | | | | | | | | | | | | | | | | | | | | | | | | | | | | | | | | | | | | REFERENCES

AMBROGI, B.G.; VIDAL, D.M.; ZARBIN, P.H.G.; ROSADO-NETO, G.H. Feromônios de agregação em Curculionidae (Insecta: Coleoptera) e sua implicação taxonômica. Química Nova, v.32, n.8, p.2151-2158, 2009. http://dx.doi.org/10.1590/ So $100-40422009000800029$

BARBOSA, P.O.; PALA, D.; SILVA, C.T.; SOUZA, M.O.; AMARAL, J.F.; VIEIRA, R.A.L.; FOLLY, G.A.F.; VOLP, A.C.P.; FREITAS, R.N. Açai (Euterpe oleracea Mart.) pulp dietary intake improves cellular antioxidant enzymes and biomarkers of serum in healthy women. Nutrition, v.32, n.6, p.674-680, 2016. http://dx.doi.org/10.1016/j.nut.2015.12.030

BARRETO, M.R.; LINO NETO, J.; ANJOS, N. Dimorfismo e razão sexual em pupas e adultos de Spermologus rufus Boheman 1843 (Coleoptera: Curculionidae). Ciência e Agrotecnologia, v.23, n.2, p.358-364, 1999.

;ROSADO-NETO, G.H. Dimorfismo sexual de Onchoscelis germari (Boheman) (Coleoptera: Curculionidae). EntomoBrasilis, v.5, n.3, p.242-245, 2012.http://dx.doi.org/10.12741/ebrasilis.v5.i3.203

CAZADO, L.E.; O'BRIEN, C.W.; CASMUZ, A.S.; GASTAMINZA, G.A.; MURÚA, M.G. Sexual dimorphism of Rhyssomatus subtilis (Coleoptera: Curculionidae). Florida Entomologist, v.97, n.4, p.1812-1815, 2014. https://doi.org/10.1653/024.097.0457

CORDEIRO, G.; ANJOS, N.; SILVA, C.R.; LEMES, P.G. Morfometria externa na diferenciação sexual de Oncideres saga (Dalman, 1823) (Coleoptera: Cerambycidae). Revista Brasileira de Zoociências, v.13, n.1-3, p.111-115, 2011

FERNANDES, L.C.; ANJOS, N.; SILVEIRA, R.D. Dimorfismo sexual em Metaxyonycha angusta (Perty, 1832) (Coleoptera: Chrysomelidae). Acta Scientiarum. Biological Sciences, v.27, n.2, p.125-127, 2005. http://dx.doi.org/10.4025/actascibiolsci.v27i2.1321
FONSECA, A.J.; MENEZES, C.W.G.; SANTOS, C.A.; ASSIS JÚNIOR, S.L.; FONSECA, A.G.; SOARES, M.A. Morfometria de pupas e adultos de Rhinochenus stigma Linnaeus 1758 (Coleoptera: Curculionidae). Revista Árvore, v.38, n. 1, p.25-30, 2014. http:// dx.doi.org/10.1590/SO100-67622014000100002

GEORGE, J.; MORSE, W.C.; LAPOINTE, S.L. Morphology and sexual dimorphism of the weevil Myllocerus undecimpustulatus undatus (Coleoptera: Curculionidae). Annals of the Entomological Society of America, v.108, n.3, p.325-332, 2015. https://doi. org/10.1093/aesa/sav013

GOSIK, R.; ŁETOWSKI, J.; KOZAK, E. Morphology of the mature larva and pupa of Diplapion confluens (Kirby, 1808) (Coleoptera: Apionidae). Polish Journal of Entomology, v.79, n.3, p.211-221, 2010.

INSTITUTO BRASILEIRO DE GEOGRAFIA E ESTATÍSTICA (IBGE). Produção da Extração Vegetal e da Silvicultura 2016, v.31, p.154, 2017. Available from: <https://biblioteca.ibge.gov.br/ visualizacao/periodicos/74/pevs_2016_v31.pdf>. Access on: Sep. 102018.

NOGUEIRA, O.L.; FIGUEIRÊDO, F.J.C.; MÜLLER, A.A. Açaí. Belém: Embrapa Amazônia Oriental, 2005. 137 p. (Sistemas de Produção, 4). Available from: <https://ainfo.cnptia.embrapa.br/ digital/bitstream/item/125409/1/SISTEMA-PROD-4-ONLINE-. pdf >. Access on: Jun. 82016.

NUNES, A.B.; RONCHI-TELES, B.; SPIRONELLO, W. Comportamento de estridulação em Heilipus odoratus Vanin \& Gaiger (Coleoptera, Curculionidae, Molytinae). Revista Brasileira de Entomologia, v.53, n.3, p.334-336, 2009. http://dx.doi.org/10.1590/ s0085-56262009000300004 
OLIVEIRA, M.S.P.Biologiafloral do açaizeiro em Belém, PA. Belém: Embrapa Amazônia Oriental, 2002.26p. (Boletim de Pesquisa Desenvolvimento 08). Available from: <https://www.agencia.cnptia.embrapa.br/ Repositorio/Biologia_Floral_000gbzbqoz402wx5ok01dx9lc18awi2w. pdf $>$. Access on: Jun. 82016.

SARRO, F.B.; CROCOMO, W.B.; FERREIRA, J.M.S. Aspectos da biologia e morfologia da broca do pedúnculo floral do coqueiro, Homalinotus coriaceus (Gyllenhal) (Coleoptera: Curculionidae). Neotropical Entomology, v.33, n. 1, p.7-12, 2004. http://dx.doi. org/10.1590/S1519-566X2004000100003

SILVA-FILHO, G.; BAILEZ, O.E.; VIANA-BAILEZ, A.M. Dimorfismo sexual do gorgulho-da-goiaba Conotrachelus psidii Marshall (Coleoptera: Curculionidae). Neotropical Entomology, v.36, n.4, p.520-524, 2007. http://dx.doi.org/10.1590/ S1519-566X2007000400006

SOUSA, W.O.; ROSADO-NETO, G.H.; MOREIRA, M.A.B.; ZARBIN, P.H.G. Description of the larva and pupa of the papaw borer weevil Pseudopiazurus papayanus (Marshall) (Coleoptera, Curculionidae, Piazurini). Revista Brasileira de Entomologia, v.48, n.2, p.331-334, 2004. http://dx.doi.org/10.1590/ S0085-56262004000300007

SOUZA, L.A. Insetos pragas em acessos de açaizeiro em viveiro. Belém: Embrapa Amazônia Oriental, 2002. 5 p. (Comunicado Técnico, 75). Available from: <https://www.infoteca.cnptia.embrapa.br/bitstream/ doc/404866/1/com.tec.75.pdf>. Access on: Jun. 82016.
SOUZA, L.A.; CELESTINO FILHO, P.; SILVA, A.B. Principais pragas do dendezeiro e seu controle. In: VIÉGAS, I.J.M.; MÜLLER, A.A. A cultura do dendezeiro na Amazônia brasileira. Belém: Embrapa Amazônia Oriental; Manaus: Embrapa Amazônia Ocidental, 2000. 374p.

TREVISAN, O.; OLIVEIRA, L.E. Danos de Ozopherus muricatus (Coleoptera, Curculionidae) em açaizeiro no estado de Rondônia. In: CONGRESSO BRASILEIRO DE ENTOMOLOGIA, 24., 2012, Curitiba. Anais... Londrina: SEB, 2012. Available from: <http:// www.seb.org.br/asp/cbe2012/trabalhos/385/385_2.pdf>. Access on: Jun. 82016 .

VAURIE, P. The weevil genera Homalinotus and Ozopherus of the neotropical Cholinae (Coleoptera, Curculionidae). Bulletin of the American Museum of Natural History, v.152, p.1-50, 1973.

WILHELM, G.; HANDSCHUH, S.; PLANT, J.; NEMESCHKAL, H.L. Sexual dimorphism in head structures of the weevil Rhopalapion longirostre (Olivier 1807) (Coleoptera: Curculionoidea): a response to ecological demands of egg deposition. Biological Journal of the Linnean Society, v. 104, n.3, p.642-660, 2011 . https://doi. org/10.1111/j.1095-8312.2011.01751.x

YAMAGUCHI, K.K.L.; PEREIRA, L.F.R.; LAMARÃO, C.V.; LIMA, E.S.; VEIGA-JUNIOR, V.F. Amazon acai: Chemistry and biological activities: A review. Food Chemistry, v. 179, p.137-151, 2015. https://doi.org/10.1016/j.foodchem.2015.01.055 